\title{
Third Party Rights in Authorization by Ratification at the PICC, PECL and Iranian Law
}

\author{
Ahmed Heidari ${ }^{1}$ \& Seyed Hekmatollah Askari ${ }^{2}$ \\ ${ }^{1}$ Is lamic A zad University, Unit of Shiraz, Iran \\ ${ }^{2}$ Law School, Islamic A zad University of Shiraz, Iran \\ Correspondence: Seyed Hekmatollah Askari, Law School, Islamic Azad University of Shiraz, Iran. E-mail: \\ lawyer.jam@gmail.com
}

Received: April 11, 2016 Accepted: June 17, 2016 On line Published: July 31, 2016

doi:10.5539/jpl.v9n6p137 URL: http://dx.doi.org/10.5539/jpl.v9n6p 137

\begin{abstract}
Agency refers to a contract whereby a person selects another one to do his affairs. It is obvious that agency can be fulfilled in different ways, including explicit authorization and authorization by ratification. Authorization by ratification is ineffective for some contracts and it faces challenges in practice, because it follows the fulfillment of two rights, one the principal's right for ratification, and the other the third-party's right to be free from the obligations of an ineffective contract. This article has dealt with the positions of two important International Instrument of Human Rights as well as that of Iran's domestic law regarding the scope of the use of ratification right by the principal and the owner of the authority right on the one hand and the rights of a third party on the other. It seeks to answer the question whether the principal has the right of ratification in any way, or has some legal restrictions? And if there are some limits to the principal's right and access to such uncertainties can lead to further compatibility of Iranian law with International Instrument of Human Rights, based on which principles and rules can one establish a relative balance between the parties?
\end{abstract}

Keywords: agency, unauthorized actions, ratification, third party, contract

\section{Introduction}

One of the ways in which agency takes place is ratification and the authority arising from it is considered one of the fundamental principles of fulfillment of agency so that authorization is the result of ratification. In other words, one of the cases of agency is ratification or the principal's giving the agent unauthorized actions that exceed his authority. Put it simply, where an individual claims that he has done an action by name and on behalf of another person, he will have the actual authority and will have logical justification based on the agency theory after the action is ratified by the principal (Danny, 2000: 199), and it is assumed that the he has had the needed authority to perform that particular contract from the very beginning. According to this theory, ratification of the agent's unauthorized actions creates a legal relationship between the principal and a third party (Danny, 2000: 199), because, when someone transacts someone else's property in an unauthorized way, agency cannot be fulfilled because he has had no authority for that action. With the lack of fulfillment of agency, the contract has no legal influence over the authority owner. However, his ratification and consent will fulfill the condition of agency, which is consent and authority and it is assumed that agency is based on the principal's explicit and actual authority before everything. However, it should be said that there has already been and can be no agency relationship between the principal and the agent and authorization has only been for the fulfillment of the agency and acceptance of its effects, i.e. the creation of a legal relationship with a third party.

Against the ratification right and its consequences lie a third-party rights which will endanger their rights.

With this description, this is considered one of the challenging issues between national legal systems and International Instrument of Human Rights. In this article, this important is sue has been studied in the two legal documents of UNIDRPOIT and principles of European contract law on the one hand and in the Iranian law on the other in order to specify their similarities and differences and thus provide appropriate strategies for further adaptation of domestic law with the rules and regulations of those International Instrument of Human Rights and their innovations can be used simu ltaneously.

UNIDROIT Principles are among the important achievements of the International Institute for the Unification of 
Private Law, which has made all its attempts for the integration of the me mbers' private law. These principles have been changed and modified several times, the latest edition of which dates back to $2010 \mathrm{AD}$.

The main focus of this article is on these principles, but the criteria of European contract law have been studied as well. This regulation is also another one of the most important documents formulated in seventeen chapters regarding the general rules of dealings by the European Contract Law Commission and the cooperation of a number of pro minent ju rists of the European Union in order to unify the structure of Eu ropean contract law.

\section{The Conditions of Ratification}

\subsection{General Rule}

UNIDROIT Principles has expressly approved the principal's right to ratify the unauthorized actions which are outside the agent's authority. European principles also has the same position. With the adoption of such a rule, it can be concluded that the unauthorized actions can always be ratified.

According to Clause 1 of Article 9.2.2 of UNIDROIT principles about ratification: "The actions taken by the agent without having the authority or beyond the scope of his authority may be ratified by the principal. If ratified, the agent's actions will create the same effect as when having the primary authority required."

Article 3-207 repeats of European principles the same rules exactly, except that the title of the Article 207-3 of European principles has been expressed more completely than that of the Principles, in that it has used the phrase "ratification by principal" instead of "ratification. However, there was even no need to mention the term "principal", because, in any case, it is the principal who must approve the illegal and unauthorized actions. Moreover, the princip les of UNIDROIT have dealt with ratification and its effects in Clause 1 of Article 9.2.2 and dealt with the time and way of ratification in in Clauses 2 and 3. However, Eu ropean principles have mentioned such cases under Article 208-3, with the title "third party rights".

It seems that ratification ways, effects and time are among the rights of the parties, i.e. the principal and the third party, and is also one of the principal' obligation toward the third party, without the third party's having any obligation in this regard ${ }^{1}$.

In Iranian law, this general rule has also been stated. According to Article 667 of the Civil Code, the attorney should observe and respect the client's interests in his actions and should not exceed what the client has exp licitly has authorized him to do or what is with in the scope of h is authority based on the custom and practices. Th is article has focused on the agent's prohibition from exceeding the authority he has been given. In other words, the agent should avoid doing anything outside the actual authority gran ted to him either exp licitly or implicitly ${ }^{2}$. A lthough this legislator's prohibition has no commercial guarantee, this commercial guarantee may be proved by reliance to Articles $1073^{3}$ and $1074^{4}$ of this law. It may, however, be said that these articles are qualified only in marriage contract. Yet, they should be understood accurately, as they are as sociated with the general rules of contracts, and is by no means limited to the marriage contract (Katoozian, 658). However, if these articles were not available or were not documented, it is principally the case that prohibition on dealings does not indicate their corruption (Mozafar, 1/311-312).

The positions of Articles 667, 1073 and 7074 of the Civil Code regarding the agent's withdrawal is a granted authority, but there are also instances in this law, which has regarded the verdict of non-influence even in the absence of any authority. According to Article 247 of the Civil Code, the dealing of another person's property is not valid but as proxy or subrogation or succession, even if the property owner is inwardly pleased; however, if the owner or his deputy allowed for that after the dealing, the dealing will be valid or binding. Although this article includes all instances and it is one of the general rules of contracts, it needs be said that this is the case where there is the possibility of subrogation (Ibid, 226), unless the law has a certain verdict.

\subsection{Ratification Time}

The problem about ratification is that the granting of authority between ratification and non-ratification to the principal will keep the third party undecided for a long time. Th is is the cost imposed on the third party and makes such contracts risky and precarious contracts, because the principal has the right to select the third party's obligation through the contract's terms via ratification on the one hand, and the harms and risks are all imposed on

${ }^{1}$ PICC, Art. 2.2.9(1).(2).(3); PECL, Art. 3:207, 3:208

2 Article 663 of the Civil Code: Attorneys cannot do an action that is out side the limits of his power.

${ }^{3}$ If an attorney does beyond what the client has already determined about the person or topic or other characteristics, the accuracy of the contract will depend on the client's ratification.

${ }^{4}$ Article 1073 is binding in cases where proxy has had no conditions and the attorney has not observed the client's interests. 
the third party on the other. Thus, if the principal does not find a contract economical, he will avoid ratifying it, but if he finds the conditions of a contract and the market of interest to him, he will make the third party obliged to the contract's terms via ratification of the contract. However, the application of this right is not unconditional, and the principal enjoys this right only when the circumstances, and the officious seller's at the time of conclusion of the contract is such that it can be implied that he has done such actions on behalf of the principal. As a result, if the circumstances, and the officious seller's performance and behavior at the time of agency does not indicate action on behalf of the principal, the imposition of risks and market fluctuations on the third party on behalf of the principal will be useless in this regard. However, if these conditions do not exist, regarding ratification as absolute can lead to violation of the third party rights. Thus, considering a legal time can partly make the third party rights unviolated and regulated.

Principles of UNIDROIT, and Principles of European Contract Law have no disagreement in this regard and both legal systems have a similar stance. This position of Iranian law also has a similar stance, but using other words. According to Article 252 of the Civil Code, the allowing or denying need not be immediate. If the delay res ults in a harm to a third party, he can break up the dealing. The contrary concept of this article imp lies that the third party can break up the dealing when there is a delay, and the delay has resulted in a harm (ibid. 230).

Therefore, International Instrument of Human Rights and Iranian Law do not believe in absolute and unconditional ratification right, although the conditions of ratification and the reasons for it are different in the two legal systems. However, there is no difference between the two legal systems regarding the principle of limitation.

For example, in the case of Metropolitan Asylums Board with Kingham, sons in 1890, the court said that in order for the principal to be able to have a lawsuit regard ing the contract that has been signed in an unauthorized way, it is necessary that the contract be ratified during the time limit set by the principal, or if a particular date has not been set for the ratification, the ratification must be carried out within a reasonable time. We can see that the purpose of such a judgment is nothing but to prevent harm to the third party.

In some cases, the lack of ratification in due course will lead to cancellation of the contract. For example, in another similar case, the case of Watson with Davies, the Court's verdict was that if the agent has accepted an offer outside of his control and its influence is dependent on the principal's ratification, and if the third party withdraws the offer be fore the principal ratifies the agent's action, then the principal cannot ratify that action. The influence of the offer's acceptance relies on the principal's ratification and this ratification will be effective before the offer withdrawal. Therefore, in this case, ratification has been done when there has basically been no offer (Ivamy \& Hardy, 1971: 82).

We see that in some cases if the deadline has been set by the parties, the deadline can be actually effective regarding the fulfillment of agency.

\subsection{Multiple Principals}

Some questions are raised in th is regard, first, what will ratification or rejection be like in cases where the principal includes more than one person? Should they all take part in the decision-making process? Can the ratification be divided for each person?

Accordance to the principles of European contract law, the principal's specific ratification occurs in a direct agency. According to Clause 1 of the Article 207-3, if a person "as an agent", does an action without the authority or beyond his authority, the principal can ratify his actions. We see that European Principles regard ratification to be specific to a case where an individual, while the UNIDROIT Principles consider it to be limited to the case where the agent's actions have been done in the form "disclosed" agency, because, if a non-disclosed principal is not able to claim the legal rights due to authorized agency, he will more probably not be able to claim the actions arising from non-authorized agency through ratification (Chitty, 2004: 16).

In Iranian law, there is no such distinction. There is a general rule that any type of dealing with another one's property of for another one without the authority or outside the limits of authority can be ratified on behalf of the principal unless such a dealing can basically not be delegated. Therefore, the conditions mentioned in the UNIDROIT principles saying that the right to ratify unauthorized contracts exists for the principal merely in disclosed agency are not actually found the Iranian law. However, in other respects, there exist some rules. According to Article 662 of the Civil Code, proxy should be given for an action which the client himself is capable of doing. The attorney should also be who is qualified to do it. Therefore, in such cases where the principal himself cannot grant authority even if he tends to do an action but cannot do it, agency is insignificant and not feasible. 


\section{The Third Party Rights}

The second question is that if the granted authority cannot be divided, how will the status of the other party's obligation to the contract be regarding the contract's terms?

\subsection{The Position of UNIDROIT Principles}

According to the UNIDROIT Principles, it is merely the third party who has the right to make the principal imple ment the terms of the contract, although the agent has acted outside the scope of his actual granted authority, provided that he has done that action within the limits of agency.

The Principles of European Contract Law has a different stance. According to the terms of these principles, the actions of an unauthorized agent with in the limits of actual authority regards both the third party and the associate as obliged to the terms of the contract in cases where the authority cannot be divided. Therefore, in this regard, there is no doubt as to which of the parties to a contract are free from contractual obligations, or only the third party has the right to oblige the principal. In addition, such cases cannot be regarded as being instances of uncertain dealings, because, when the granted authority has no relation with approval during a reasonable period based on the nature of the dealing of goods or services, the imposition of the terms of such a contract to a third party is possible in certain cases to be regarded as instances of gambling dealings and may be at odds with the principle of good faith and fair dealing, although considering less time for ratification may be considered in line with the principle of good faith and fair contractual ru les (Bennett, 2006: 784).

Clause 2 of Article 9.2.2 of Principles says in this regard that the third party can send a notice to the principal and sets a reasonable time for ratification. If the principal does not do the ratification with in that time period, he cannot do anything about it any longer.

A comparison of this Clause with Clause 3 of this Article shows that this Clause is used in cases where the principal is aware that the agent has no authority or acts outside the scope of the authority granted to him. The reason for granting this right to a third party is the same reason mentioned in the law of England. Such a third party has a legitimate interest in deciding about the ultimate result of the contract with the false agent so that he can get out of doubt regarding the ratification or non-ratification of the principal; otherwise, such a dealing may have a non-confirmed state about the third party and be regarded as an instance of gambling dealings.

Therefore, a third party is allowed at any time before ratification to end the principal's opportunity to use his right to ratify and misuse the deteriorating conditions of the market, only provided that such a third party is not aware of the false agent's lack of authority. Otherwise, he will only have the rights referred to in Clau se 2 of this article.

However, when the contract is concluded about a product or market services, the third party is in some cases willing in the position of the buyer to want the execution of the contract, i.e. de livery of the sold goods from the principal (the seller). In this particular case, the lack of a wareness about the agent's lack of authority creates no problem for the third party rights, because he will be able to rely on the rules and regulations of the apparent authority.

The objection to Clause 2 of Article 9.2.1 of UNIDROIT Principles is that if the third party gets no reason for his awareness of the agent's authority, he will remain as an unaware third party for a long time and the principal can ratify the contract whenever the market conditions are in his favor and to his interest. This is because this clause says that if a third party is not or cannot be aware of the agent's unauthorized actions, he can send to the other party his own lack of loyalty to the contract at any time before the contract ratification. However, if the third party does not get aware of such a state, the third party will remain unaware for any period of time before ratification, and the ratification will make him abide by the contract.

It seems that where the principal knows or should have known that the third party has no awareness of the state and is not aware of false agency he should avoid ratifying such a contract, and should, in accordance with the goodwill and fair dealings principles make the third party aware of his true position in the contract before ratifying the contract, ${ }^{5}$ or should provide conditions based on which he can refrain from accepting such ratification by providing a logical reason after the ratification.

\subsection{The Position of Principles of European Contract Law}

The Principles of European Contract Law has a different perspective about the third party rights. As it was mentioned earlier, UNIDROIT principles has determined no time limit for ratification of the false agent's actions,

\footnotetext{
${ }^{5}$ Clause 1 of Article 7-1 of UNIDROIT Principles says regarding the principle of goodwill and fair dealings that each one of the parties to a contract in international commerce should act in accordance with good will and fair dealings.
} 
whereas according to the Principles of European Contract Law, both the third party and principal are committed to the contractual terms signed within the frame work of apparent authority. In other words, when an agent acts owing to apparent authority, agency will be fu lfilled without any conditions, and with that fulfillment, the third party and the principal will be obliged to its effects. This occurs when the third party believes reasonably and by reliance on the principal's statements and conduct or based on goodwill that under the apparent authority to do anything. Representative actions can be fulfilled without any conditions attached, and with it the fulfillment of a genuine third party and are subject to its effects. Th is situation occurs when a third party reasonably relied on the statements or conduct or based on the original and in good faith believes that such an agent has actual authority. However, if the agent does an action with those conditions, the action will be an instance of agency owing to apparent authority that makes the two parties obliged to the commitments. This is because the authority for ratification or non-ratification is the legal right whereby a person can ridden himself from adhering to contractual obligations or choose the terms of the contract on his own decision. In this case, before ratification takes place, agency will make no sense, whereas under the assumption of apparent authority, agency has been fulfilled at the same time as the agent's action without any preconditions and the issue of ratification arises when the third party has no honest and reasonable belief that the agent has apparent authority.

European principles has in one particular case granted apparent authority to the third party for agency under some conditions. According to Artic le 208-3 of European principles known as third party rights formulated with regard to authority ratification, "If the principal's statements or conduct have convinced the third party that the agent has acted with authority, but the third party has doubt regarding his authority, he can send the principal a written confirmation or request ratification from the principal. If the principal objects without delay or avoids answering the request, the agent will be considered to have authority. "

These conditions are conceivable when the third party has legitimate doubt about the existence or scope of the agent's authority. In this case, the third party will have the right to do the needed inquiries from the principal in order to resolve his doubt.

However, this rule ${ }^{6}$ is related to the time when an agent does a dealing for the principal without setting a written contract. Now, the third party becomes dubious about the agent's authority according to the terms and nature of the contract, and requests for a written confirmation fro $m$ the principal. If the third party receives such a notice from the principal, the written confirmation will be considered a written contract between the parties, if it involves a number of additional terms or conditions different from the ones agreed upon, provided that the subject matter of the contract does not change.

Article 210-2 of principles of European law says in this regard: "When specialists have signed a contract, but have not set it in a final written document and one of the parties sends the other a writing without delay, imply ing the endorsement of the contract, the conditions will be considered as an integral part of the contract although it contains additional and different conditions unless the approval creates major changes in the terms of the contract, or the other party objects about the conditions and terms without delay.

Clearly, if agency takes place through actual or apparent authority, as Article 208-3 of Eu ropean Principles has given the third party mere ly the right to clarify the agent's authority, so the right is not applicable when the granted authority is apparent authority, because denying the authorities that actually exist is in fact a violation of the principal benefits of the agency theory and will be used as a plea for the third parties to deny the agent's authority at any time.

The failure to give the third party the right to deny or doubt when there is unauthorized agency is related to the time when the principal's statements and behavior necessarily convinces the third party reasonably that the agency has been authorized, only because the agent has acted in such a way as if his actions were authorized (Howard, 2006: 785).

Based on European principles, the principal's rights about the authority for ratification and non-ratification of unauthorized actions as well as his opportunity to impose the costs of such an authority on the third party to the contract has been limited in several cases.

First, when the agent's actions have actually been carried out in an unauthorized way, which can also include agency in cases of apparent authority which are actually unauthorized.

Second, the case where the third party believes that the unauthorized actions have actually taken place with in the

${ }^{6}$ Professional Written Confirmation Rule: this rule is related to cases where professional people (experts in a business job) conclude a contract. Some of their contractual conditions may not be thoroughly transparent, in which case one party to the contract requests the other party for a written confirmation including the contractual conditions that should be stated in or implied from the contract 
scope of authority, such that the agent's actions were in fact unauthorized, but the third party believes that these kinds of the agent's actions are within the scope of his authority.

Third, the principal's actions, behavior and speech are not reasonable enough for the third party to believe in authorized agency.

Here arises the question whether a principal can take advantage of an agent's unauthorized actions based the Principles of European Contract Law. European accordance with the principles of contract law can take advantage of an unauthorized acts? To answer this question, it must be said that this kind of advantage depends on compliance with a series of basic and important that were described in detail, besides the fact that this international document has introduced the principles of good faith and fair dealing as a sacred principle. In Article 201-1 under the heading "the general requirements", this document has talked of good faith and fair dealing and asserted: "Each party must act in accordance with good faith and fair dealing, and the parties to a contract cannot exclude or limit this obligation". "Based on the last clause of this Article, the principle of good faith and fair dealing has an obligatory nature, and the parties cannot set aside the requirements and obligations arising from this principle by reliance on the principle of will authority. However, this difficult does not deny that the parties to the contract can determine the vast concept of the principle of good faith and fair dealing in their contract (Antoniolli \& Veneziano, 2005: 48). Therefore, the principal cannot have a unilateral use of this stratus, unless there is an agreement on the concept and inclusion of the principle of good faith and fair dealing exist, because the purpose of these rules is to observe the common standards ${ }^{7}$ in trade agree ments.

In addition, these two systems, based on the principle of good faith and fair dealing, have set obligations for the parties and regard these principles as superior rules so that the principle of good faith and fair dealing is dominant where there is contrast between these principles and other principles. Therefore, the ratification that does not observe the nature of goodwill and fair dealing is not effective and consequently agency will also not take place (Lando \& Beale, 2000: 113), unless such principles are not accepted in those countries in accordance with their do mestic regulations and contract law.

\subsection{Iranian Law}

Regarding the third party rights in UNIDROIT principles, the following major rights had been emphasized for the third party in non-binding contracts: time and date of ratification, giving notice, determining the deadline for ratification, and rejecting the ratification in advance.

In Iranian law, the third party also has rights in order to prevent the owner of the ratification right from cause harm to him. This subject is analyzed based on the rule that in non-binding dealings, not only the principal, but also the third party has to abide by the obligations

\subsubsection{The Judicial and Legal Foundation of Third Party Rights}

The author of "Javaher" (Najafi, 2015: 359) says: "Whatever violates the legislator's motive and purpose of legislation is subject to invalidation ${ }^{8 "}$ with the interpretation that in the Islamic law, considering God's purposes and goals of Islamic law is an axiom. In public law, this principle is observed completely. In the field of private law, in cases where public order or others' interests are concerned, God's goals will be considered more. Therefore, the owners of rights should apply their rights in such a way that they create no ham to others, or their rights will be banned and stopped via the Principle of No-Harm (Bahrami Ahmadi, 2011: 2/142-145). We can see that the third party to non-binding contracts is protected by Principle of No-Harm so that the owner of the ratification right cannot apply his right in such a way that the third party rights are violated through its application. Therefore, the legal base of the third party rights is nothing but the principle of No-harm 9 .

\subsubsection{Maintaining the Generality of Agency}

Article 256 of the Civil Code provides: "If anyone transfers his or another's property via a contract or accepts the transfer of a property dealing to himself or another, the dealing to his own will be binding and to the other will be".

Based on this article, if the ratification can be divided; that is, agency can be selected and fulfilled one section and can be cancelled in another section, the principal can apply this right. However, by reliance on Article 441 of the Civil $\operatorname{Code}^{10}$, a third party can compensate for the losses resulting from this discrimination via termination of

\footnotetext{
${ }^{7}$ Decency, Fairness and Reasonableness.

${ }^{8}$ Everything violat ing the legislator's motive for legislation is necessarily invalid

9 The Fortieth Principle of the Constitution: "No one can use his rights as a means of doing harm to others of to the public interests".

10 Article 441 of the Civil Code, "option of contract invalid in part is when the sale contract is void with respect to the part of sales in a way or another, in which case the customer shall be entitled to terminate the sale contract or withdraw the price in ratio to the part which was void
} 
a part of the contract to which agency has been fulfilled. This is because the lack of ratification of one part of agency will practically be considered the non-ratification of the other part of the contract.

However, in cases where there is such diversity and ratification cannot actually be divided, and its division will cause harm to the third party, such division should be considered a new offer which needs the acceptance from the third party (Katoozian, 1995: 132/2). In such a case and with acceptance of the third party, there will be no room for discussion of agency, because the principal and the third party conclude a separate contract independently without considering the agent's unauthorized actions. In Iranian law, according to the general Non-harm rule, if the application of the principal's rights causes harm to a third party, such ratification will be considered to have the attribute of authority, but it can be rejected toward the third party. Agency will be fulfilled in these cases, but its effect will not be implemented. In other words, in some cases, agency may apply and be effective for a third party, i.e., a legal relationship can be created, but again the third party will have have the right to terminate the legal relationship by reliance on the Principle of No-harm unless he does not terminate it, in which case he has acted against himself (Bahrami Ahmadi, 2011: 1-98), and the principal and the agent will not be responsible for anything.

\subsubsection{Obligation Prior to Ratification}

The rule adopted about the pre-ratification contracts is that, the contract subject belongs to the principal prior to the ratification, as the price of the contract also belongs to the third party, because the non-binding contract does not have the conditions of purchase and ownership (Ansari, 1425: 141-2).

The question raised here is, what obligations the parties to the contract have before ratification. There is no controversy about the principal, because the contract is non-binding for him, so he has no obligation toward it. This is because the assumption is that a non-binding contract is an incomplete contract. The major controversy lies in the third party's obligation for such a contract, about which there is much disagreement among jurists. Some believe, if the effect of the consent is discovery by warrant, the third party will have the right to terminate the existing contract before the ratification, because it is assumed that the non-binding contract is an incomplete contract and the third party has the right to terminate the contract before the principal's ratification.

However, if the effect of consent is real discovery, because the contract is complete on behalf of the third party, the principal will only have the authority to terminate the contract and the third party should be considered bound by the contract. Some criticize this idea, claiming that, if the consent is the late condition in the fulfillment of the contract, or if it has a retrogressive effect, it can also be denied that pre-ratification contract is incomplete and has no obligation to the third party (Khonsary, 246/1). Others also talk exp licitly about the effects of consent (Als anhoury, 1952).

Some others believe that the non-binding contract is incomplete before the ratification and the third party has no obligation to maintain it (Tabatabai, 335/1 and 332).

There seems to be a consensus of opinion among Iranian legal experts. They believe that we should differentiate between the final effect of the contract and the third party's obligation toward the terms that he has committed, in that the effect of a non-binding contract is supplied in the principal's assets or his ratification, but there is no obstacle in the third party's loyalty to this contract (Katoozian, 1995: 141).

In other words, they say that the unauthorized dealings to another person's property is not valid without the principal's consent, and will become valid at the time of his ratification, no matter the third party is aware or unaware of the officious dealings. If the third party is unaware of the officious dealing, his disclosure will be ineffective to the others (Shahidi, 2004: 36, 38).

It can be implied that when the third party's disclosure against the principal is effective, $h$ is disclosure and consent to himself will be effective. According to the principles of will authority and freedom of contract and unilateral irrevocability, the third party should be loyal to the terms of the retrogressive contract. The last part of Article 252 of the Civil Code reads: "... the dealing can be violated by the one referred to" confirms this view, since the term "violation" cannot have a mean ing other than termination, and termination also implies the authority to eliminate the contractual obligations.

However, the third party's obligation to the terms of such contracts also have the following exceptions.

1) The character of the party to the dealing from the third party's perspective is the major cause of contract. If the third party knew him at the time the contract was signed, he would sign the contract with him. Here the third party cannot be bound to the contract terms because it was in conflict with the principle of freedom of contract

sales". 
(Katoozian, 1995: 143 and 142).

2) According to Article 252 of the Civil Code, if the delay in ratification causes harm, the third party will have the right to terminate the contract and be exempted from the obligations of the contract. The same rules are used in Egyptian law based on Article 990 of the Egyptian Civil Rights Act (Alsanhoury, 1952).

\section{Conclusion}

A comparis on of UNIDROIT princip les and the principles of European contract law with Iran ian law on the third party rights in authorization arising from ratification showed that:

1) In the three legal systems, the contract concluded by authority-free persons or signed off outside their authority are among contracts that can be completed with subsequent consent and can obtain all their legal effects owing to ratification.

2) In all of the three legal systems, authorization arising from ratification was adopted so that, after ratification, the unauthorized agent has the needed authority for the conclusion of that contract at the time of con clusion. In other words, ratification has a retrogressive effect and its effects are considered valid since the agent's action.

3) Considering banddddd 2, one comes to the conclusion that authorization arising from ratification has been accepted in those legal systems and as a result of ratification, the implementation of legal relations between the principal and the third party would be justified by the agency theory.

4) It has been observed that there are no differences in the generalities of these legal systems. If there are diffe rences, they are related to "phrases and words" which will not change the nature of the legal terms.

5) All of the three legal systems have considered for the principal and the owner the right to act considering their interest owing to their free will through the authority to select between the ratification and rejection of non -binding contracts, but the application of such a right should not cause harm to another person.

6) Iranian law has generally considered the right to terminate the dealing for a third party, provided that the ratification is delayed and the delay would be against him without limiting such a right to certain time and a certain deadline. Second, Iran's law has not differentiated the ratification between the third party unaware of unauthorized agency and the third party aware of it. However, in International Instrument of Hu man Rights, the third party, whether aware or unaware, has the right to send a notice to the principal and determine the reasonable time for ratification ${ }^{11}$.

7) In European contract law principles, attempts are made to reduce the necessity or obligation of contracts, believing that if the terms and conditions of the apparent authority theory were not applicable, one could resort to the terms of the theory of authorization by ratification, considering the third party rights.

8) In International Instrument of Human Rights, if the third party is unaware of the agent's unauthorized, he can send a notice to the principal at any time before ratification to tell him that he has no obligation or loyalty to the contract, while this is not authorized in Iranian law ${ }^{12}$.

\section{References}

Ahmad Alsanhoury, A. (1952). Mediu m commentary on the new Civil Code, Vol. 1, Beirut, Arabic Darolehya.

Ansari, M., Almakaseb, Vol. 3 \& Vol. 6., $7^{\text {th }}$ Ed., Islamic Thought Society, 1425.

Antoniolli, L., \& Veneziano, A. (2005). Principles of European Contract Law and Italian Law. The Hahge, Kluwer Law International.

Bahrami, Ahmadi, H. (2011). The Rules of Jurisdiction (No-harm Principle) (Vol. 2., 2nd ed.). Tehran, Imam Sadegh (AS) University.

Bennett, H. (2006). Agency in the principles of European contract Law and the UNIDROIT principles of International commercial contracts . uniform law Review, II.

Chitty, J. (2004). Chitty on Contracts (Vo1. 2). London, Sweet \& Maxwell.

Danny, B. (2002). The principles of European contract Law and Dutch Law, commentary, Nijmegan [u.a.] Ars Aequi libri [u.a.].

Ivamy, E., \& Hardy, R. (1971). Casebook on Agency. London, Butter worths.

${ }^{11}$ PICC, Art, 2-2-9(2)

12 PICC. Art, 2-2-9(3) 
Katoozian, N. (1995). Civil Law, the General Rules of Contracts (V1. 2). Enteshar Company.

Khansari, M. (n. d.). Mirza Hassan Naeini's Speeches (Description of Makaseb), Vol. 1.

Lando, O., \& Beale, H. (2000). The principles of European contract Law, parts I and II, prepared by the commission European contract Law, Kluwer Law International, The Hague, London, Boston .

Mozafar (Allameh), Sheikh Mohammad Reza. (n.d.). The Principles of Jurisdiction (Vol. 1, 4th ed.). Beirut, Daroltaarof.

Najafi, M. (2015). Substantial Talks in Description of Islamic Rules. Tehran, Islamic Book House, Soltani Market.

Principles of European Contracts Law. (2004).

Principles of International co mmercial contracts. (2010).

Shahidi, M. (2004). The Principles of Contracts and Obligations (3rd ed.). Tehran, Majd Scientific and Cultural Society.

\section{Copyrights}

Copyright for this article is retained by the author(s), with first publication rights granted to the journal.

This is an open-access article distributed under the terms and conditions of the Creative Commons Attribution license (http://creativecommons.org/licenses/by/4.0/). 